University of Nebraska - Lincoln

DigitalCommons@University of Nebraska - Lincoln

1996

\title{
THE GREAT PLAINS SIT-IN MOVEMENT, 1958-60
}

Ronald Walters

Howard University

Follow this and additional works at: https://digitalcommons.unl.edu/greatplainsquarterly

Part of the Other International and Area Studies Commons

Walters, Ronald, "THE GREAT PLAINS SIT-IN MOVEMENT, 1958-60" (1996). Great Plains Quarterly. 1093.

https://digitalcommons.unl.edu/greatplainsquarterly/1093

This Article is brought to you for free and open access by the Great Plains Studies, Center for at DigitalCommons@University of Nebraska - Lincoln. It has been accepted for inclusion in Great Plains Quarterly by an authorized administrator of DigitalCommons@University of Nebraska - Lincoln. 


\title{
THE GREAT PLAINS SIT-IN MOVEMENT, 1958-60
}

\author{
RONALD WALTERS
}

In 1960, black youths conducted a "sit-in" in Greensboro, North Carolina to obtain the right to eat at a segregated lunch counter. Others quickly replicated sit-ins throughout the South and, just as quickly, the press labeled Greensboro the "first" sit-in. Historian David Levering Lewis, for instance, said: "There were not a few white southerners, and probably a majority of white northerners, who would have wished to say to the first sit-in students, as did the woman in the Greensboro Woolworth's, 'you should have done this ten years ago."' Even data-oriented social scientists such as Doug McAdams portray the sit-ins as "beginning in early February of 1960...."

Ronald Walters, a participant in the sit-in that is the subject of this paper, is currently professor and chairman of political science at Howard University, Washington, D.C. One of his four books, Black Presidential Politics in America (1989), won the Ralph Bunche Prize from the American Political Association.

[GPQ 16 (Spring 1996): 85-94]
Some studies of the NAACP during the civil rights movement mention Oklahoma sit-ins but do not mention Wichita, Kansas at all. ${ }^{2}$ And yet the first modern sit-in may have been in Wichita.

These accounts are inaccurate and incomplete but they also symbolize the extent to which the civil rights movement in general has been written about almost exclusively from the perspective of what occurred in the South. Considering that journalists wrote the first accounts, it may have been their initial perspective that was responsible for the subsequent lapse by serious scholars.

For example, in the throes of the Montgomery Bus Boycott in 1956, the editor of the Montgomery Advertiser, Grover Hall, Jr., challenged northern journalists to report on northern race friction. Hall wrote U.S. News and World Report describing how northern papers such as the Minneapolis Morning Tribune and the Chicago Daily News put the Montgomery story on the front page and news about their own race friction on the back pages. Obviously, to the northern editors, the most newsworthy incidents of race relations were occurring in the South, where challenges to 
age-old social practices, originating in the institution of slavery, were taking place. ${ }^{3}$

At first Pulitzer Prize-winning editorial writer Lauren Soth, of the Des Moines Register, was typical of those who responded, saying that this southern focus was natural, since "the [race] problem simply did not exist" in the North. ${ }^{4}$ Nevertheless, his and a host of other papers subsequently carried stories about their own racial problems, but because the drama in the South was created by the danger of blacks challenging the existing racial order, the real story of civil rights was still covered as the southern story.

One casualty of this perspective is that scholarship on many northern aspects of both the civil rights movement and the more aggressive black liberation movement have been neglected. As Howard Zinn was to suggest, after the Montgomery Bus Boycott, the movement for social change in the South moved slowly. ${ }^{5}$ The significance of the sit-in movement was that it electrified southern activists as a model for action throughout the South. Besides challenging segregation at lunch counters and restaurants, the movement quickly became elaborated into many other tactics of confrontation, such as "kneel-ins" at churches, "wade-ins" at swimming pools, "stand-ins" at voter registration places, and others.

In perhaps the major scholarly work on sitin movements, sociologist Aldon Morris stated that despite the Greensboro sit-in's mythic status as the "first," others had occurred in at least fifteen cities between 1957 and February $1960 .{ }^{6} \mathrm{His}$ study of the linkage between the Greensboro event and other such actions in the South, however, confirmed its quickening effect on the entire movement. He sought to analyze the sit-ins within the context of resource mobilization theory, which posited the importance of preexisting social supports within the black community, such as civil rights organizations and churches. Political scientist Doug McAdams's data also indicates the important function of sit-ins and that student groups associated with the NAACP, churches, or colleges initiated 75 percent of sit-ins or other direct-action tactics in the movement. ${ }^{\text {? }}$

Morris's research also revealed that two of the earliest of the modern sit-ins occurred in Wichita, Kansas, and Oklahoma City, Oklahoma, under the auspices of the NAACP Youth Councils. ${ }^{8}$ In an early article, Morris, following the seminal work of Martin Oppenheimer, repeated an error in stating that: "the first sit-in cluster occurred in Oklahoma in 1958 and spread to cities within a hundredmile radius . . " ${ }^{9}$ Later, after considerable primary research, he said in his comprehensive work on the subject: "Less than a week after [the sit-ins] in Wichita, Clara Luper's group in Oklahoma City initiated its planned sit-ins." 10 Thus, one objective of this paper is to establish the correct sequence of events among the chain of early sit-ins occurring in the Great Plains that were precipitating events for social action in that region as well as in the South. ${ }^{11}$

Second, as a result of the journalistic treatment referred to above, as well as early work such as that by Oppenheimer, which appears to divorce the Great Plains movement from the South, scholars have viewed the early Great Plains sit-ins as isolated events. In fact, as a political tactic in confronting segregation based on racial discrimination, they had a historical sequence that had been pioneered by the Fellowship of Reconciliation and the Congress of Racial Equality as early as the 1940s. The importance of the Wichita and Oklahoma City sit-ins, and others in the pre-1960s period, was their proximity to the modern civil rights movement, their linkage to the sit-ins that did occur beginning in 1960, and their engagement of the generation of post-World War II youth in the process of social change.

\section{THE WICHITA SIT-IN}

Census data show that between 1950 and 1960 the total population of Wichita, Kansas, grew very quickly, from 168,000 to 255,000 , and by 1960 its black population was nearly 
$20,000 .{ }^{12}$ This was a significant pattern of postWar population growth made possible by a developing aircraft industry, which, although it was structured to serve wartime production, rapidly made the transition to commercial markets. Indeed, national publications could write of Wichita as a "boom city" when a house-building frenzy took the city to twice its 1945 size.

Growth was made possible by such giants as Boeing Airplane Company, which became the largest employer, moving from 1402 workers immediately after WW II to 25,855 by 1955 , with an annual payroll of $\$ 126$ million. The city had also become a magnet for companies building popular small commercial aircraft such as Cessna and Beech Aircraft Company, each with about one-third the sales of Boeing. ${ }^{13}$

But although the rising economy incorporated a segment of the black community who worked in aircraft and related industries, the social fabric of the city was distinctly segregated. Although Kansas had "bled" to keep slavery from its territory, Wichita resembled a Southern city in the occurrence of murder and lynching of blacks. ${ }^{14}$ Blacks had suffered a long history of discrimination and segregation in Wichita and even by the 1950s, although public transportation was integrated, blacks were not welcome in white elementary schools, theaters, churches, restaurants, parks, or other places of public accommodation. According to Robert Newby, participant in the Wichita sit-in and professor of sociology at Central Michigan University, "In the South, everything was marked 'white' or 'black.' Just over in Kansas City [Missouri] signs were everywhere. But in Wichita there were no signs. Everyone just knew the rules and that you didn't break them." ${ }^{15}$ Complaints of discrimination in employment were commonplace as the rising middle class of doctors, lawyers, postal clerks, and education professionals struggled for upward mobility.

As they had in many such communities, Wichita blacks had established a small but active NAACP chapter in the 1920s. The several chapters located in cities throughout
Kansas, headed by state conference president Dr. C. A. Rocquemore, defined both racism and its opposition. The Wichita NAACP was headed by a youthful and dynamic attorney, Chester I. Lewis, and the December 1958 issue of The Crisis, the magazine of the NAACP, carried pictures of the local and state officers.

The Wichita Youth Council of the NAACP was headed from 1958 to 1960 by Ronald Walters, then a local college student, the author of this article. The Youth Council included high school and college-age youth, the Little Rock generation. The Council was a novelty, since youth had not featured prominently in social change movements until this time. The Council recognized that nowhere in the city could blacks sit down to eat in a dignified manner in white-owned restaurants. The many blacks who worked downtown suffered from this disadvantage as well as the slight to their humanity of being served while standing behind a board at the end of the lunch counters at F.W. Woolworth, Kress and Company, and other stores.

In the spring of 1958, the Youth Council decided to integrate the lunch counters downtown and selected Dockum Drug Store, a Rexall pharmacy located on one of the busiest midtown intersections, at Douglass and Market streets. This idea came from a meeting with attorney Franklin Williams, then west coast regional secretary of the NAACP, who visited Wichita and explained the sit-in tactic used at UCLA to integrate the main dining hall in the 1940 s. ${ }^{16}$ Once the Youth Council had decided to act, it held workshops on how to conduct the actual sit-in in the basement of the St. Peter Claver Catholic church.

The Council employed a comic book on the method of non-violence, prepared by the SCLC, one of more than 2500 such books that had been distributed all over the country. Chester Bowles, later U.S. Ambassador to India, wrote about the techniques covered in the comic book in an article about using Gandhi's teachings to achieve civil rights. In the pamphlet: 
... a Negro preacher said to his congregation: "Now let's practice it again. I'm white man and I insult you, I shove you, maybe I hit you. What do you do?"

\section{Answer:}

"I keep my temper. I do not budge. I do not strike back. I turn the other cheek." 17

The Youth Council taught this non-violent method as part of their training for the actual sit-ins. They felt that this method, even though its users were not reflecting a particular religious practice, would give the demonstration both moral authority and discipline.

The sit-in began on Saturday, 12 July 1958 and lasted for several weeks. ${ }^{18}$ Each of the twelve to fifteen youths who participated was to march in, sit on the stools at the lunch counter, and ask for service. After being refused the young demonstrators continued to sit silently on the stools. ${ }^{19}$ According to a reporter, "On a bright warm Saturday morning in July 1958, young Carol Parks [vice president of the Youth Council] breathed deeply, opened the door to the Dockum Drug Store in downtown Wichita and sat on one of the eight stools at the lunch counter... [She explained,] 'This was my first experience with fear.'"20 Eventually each time demonstrators arrived the lunch counter put out a sign reading, "This Fountain Temporarily Closed," which told the victorious demonstrators that they were forcing the restaurant to forego income in order to practice racial discrimination. The sit-in pattern was repeated without much conflict, except the usual comments from dissatisfied customers. One potentially serious challenge from a considerable number of young white toughs was thwarted by the presence of the police. $^{21}$

The black community slowly became aware that the sit-in was occurring, but the adult chapter of NAACP in Wichita did not support it because at that time the national office was cool to direct action tactics, favoring legal strategies instead. ${ }^{22}$ There was consider- able ambiguity and even fear among the adults concerning how whites would react to the sitin, so a significant number of youths continued to form the support base for the movement.

The sit-in continued until 7 August, when Walter Heiger, manager of the Dockum Store, announced that he would serve everyone without regard to race. Carol Parks remembered that it ended without statement or fanfare from the participants because everyone was emotionally drained. ${ }^{23}$ It was Chester Lewis, the Wichita NAACP head who had been supportive of the action, who broke with his colleagues and the national office to pronounce the sitin a victory, indicating that he did not know what "right" proprietors were defining when they asserted the right to do something against the Judeo-Christian precepts of the country. ${ }^{24}$

\section{THE OKLAHOMA SIT-IN}

Oklahoma City was a somewhat larger city than Wichita, but they shared a similar culture, even though people in Wichita considered themselves more "northern," with all the status distinctions that implied. Oklahoma was more southern in terms of its culture and racial feelings and the barriers constructed against the black community. Oklahoma City had also experienced significant growth between 1950 and 1960, expanding from 244,000 to 324,000 , with a black population of 12 percent, or about 35,000 , by $1960 .{ }^{25}$

In parts of Oklahoma, including Oklahoma City, the signs that marked a segregated society were occasionally in evidence, but its oil and agriculture sectors sparked economic progress for many, even some blacks. Prosperity, as in other cities, created upward mobility that inevitably led blacks to challenge the racial barriers.

In 1957 the Oklahoma City Youth Council planned to oppose lunch counter discrimination. ${ }^{26}$ They selected five stores: John A. Brown Luncheonette, Veazey's Drug Store, Katz Drug, Kress, and Green's Variety Store (ultimately not confronted because the management relented). ${ }^{27}$ The Council was led by Barbara 
Posey, a dynamic fifteen-year-old, and its adult adviser was Ms. Clara Luper, a strong and committed NAACP veteran. The group negotiated unsuccessfully by letter with representatives of the Katz Drug Store chain during 1958 , and most attempts to speak directly with the store managers were unsuccessful as well.

Thus, on 19 August 1958 a lunch counter sit-in was launched against the Katz Drug Store, located at 200 West Main, by eight youths from five to fifteen years of age. They requested service and when they were refused, they asked for the store policy on discrimination. The store manager, J. B. Masoner, explained that the store policy was not to serve Negroes, so they remained seated at the lunch counter. ${ }^{28}$ When asked by reporters about the sit-in, James Stewart, President of the Oklahoma adult chapter of NAACP said that this "test case" was supervised by the Youth Chapter and added: "I believe there has been one just recently in a drugstore in Wichita, Kansas." 29 The initial Oklahoma City demonstration lasted two days before the store manager decided to serve the youths.

From this successful venture, the youths moved their protest to the Kress and John A. Brown luncheonettes. At Kress they were served, ${ }^{30}$ but John A. Brown refused to provide integrated service despite often daily sitins. Nevertheless, Barbara Posey evidenced a faith that their movement would ultimately be successful:

I am convinced that Oklahoma people are strong, eager and youthful at heart. They have a spirit which is called the Sooner Spirit. This spirit gives people a firm belief in themselves and in the future. It points with pride to what has already been done in the peaceful integration of buses, theaters, and schools and looks forward to the day when segregation in all public eating places will be abolished. I do not believe that John A. Brown's and other restaurants owners will continue to hold on to a long lost dream of white supremacy. ${ }^{31}$
One may infer from this statement that the youthful leader was driven by a deep religious conviction. Aldon Morris has pointed to the significance of community resources such as churches in the movement, and although, except for one training session, churches were not involved in the Wichita sit-in, Calvary Baptist appeared to be a central organizing place and staging area for the Oklahoma movement. On 10 August 1960 a group of 104 youths went single-file from the Calvary Baptist Church at Northeast Third and Walnut Streets to the Cravens Building, where they mingled in the lobby and asked to be served at the Anna Maude Cafeteria. ${ }^{32}$ Other churches contributed both space and funds to the movement. The Reverend Glenn Smiley, a Methodist minister who worked for the Fellowship of Reconciliation (FOR), came to the city and conducted non-violence workshops at Calvary. Journalist Kyle Ragland says that Smiley indicated that "Sit-ins are 'essentially a religious protest and movement. ...'Although the $\mathrm{Na}$ tional Association for the Advancement of Colored People-a secular group-has been active in sit-ins, there frequently is a strong link with church members and leaders." ${ }^{33}$ FOR would be an important trainer in subsequent sit-ins occurring in many Southern cities.

The adult leadership of the NAACP strongly supported the youth protestors. Dr. E. C. Moon, Jr., president of the Oklahoma NAACP, led a small group of protesters at Calvary in singing "America" before they went out. In February 1959, Chester Lewis, head of the Wichita branch of the NAACP, had come to Muscogee, Oklahoma, to speak to about three hundred NAACP Youth Council members. He reminded them of the courage it took to fight for freedom and then appealed directly to the adult chapter to support the movement. An editorial in The Black Dispatch, a local black newspaper, backed up Lewis:

We feel that this suggestion is appropriate to the youth movement in Oklahoma city. For several months, members of the local 
NAACP Youth Council have been trying to obtain first-class citizenship in places of public accommodation. They have been partially successful. But where they have failed it was because of ungiven support of adults. $^{34}$

When the sit-in began in Oklahoma City in 1958, the state executive committee of the NAACP released a statement by the national office stating that they "wholeheartedly endorsed the efforts of the local NAACP chapter to gain first-class citizenship for Negroes." ${ }^{35}$ The executive committee also expressed sympathy for sit-ins in other cities where the national office had not extended sponsorship or support. The Youth Council acknowledged this endorsement but decided not to substitute adults for the high school and college youth it was recruiting to continue the protest. ${ }^{36}$ In any case, the endorsement may have signaled a change in the policy of the national office toward local direct-action tactics like the sitins, and in Oklahoma they continued from 1958 to 1961 .

One direct effect of the Oklahoma City sitins was that a bill was introduced into the state legislature of the adjacent state of $\mathrm{Ar}$ kansas to prohibit sit-ins. The bill provided for a protester to be fined and imprisoned for refusing to leave any business establishment other than a common carrier. ${ }^{37}$ When the Oklahoma sit-ins became national news, they exposed the weakness of the U.S. Civil Rights Commission. The commission held a news conference in September of 1958, to announce its agenda, but when a reporter asked Chairman John Hannah whether the commission would intervene with relief for the Oklahoma demonstrators, Hannah admitted that the commission was powerless to act, since it had been given no mandate by Congress. ${ }^{38}$ The Oklahoma sit-ins spread immediately to Enid and Muscogee, which became integral to mobilizing the state NAACP behind the movement. ${ }^{39}$ By 1960 the demonstrations were statewide.

\section{Relevance of the Great Plains}

SIT-INS

As indicated above, civil rights scholars have tended to view the Great Plains sit-ins as isolated phenomena. For example, Aldon Morris says that "Greensboro would have happened with or without Wichita," and Clayborne Carson, editor of the Martin Luther King, Jr., Papers, has said that the Wichita sitin had no effect on Greensboro- "the drama of race occurs in every locality." 40

While these are credible opinions, they are by no means the last word on the matter. Given the links between the Wichita sit-ins and those in Oklahoma and the links between the Oklahoma sit-ins and the rest of the country, while "Greensboro would have happened with or without Wichita," it would likely have happened in another manner and perhaps in another place and time. The NAACP Youth Councils and the nationwide NAACP network would have been different if the Great Plains Youth Councils had not pioneered the sit-ins. Consider these two critical linkages:

The Wichita-Oklahoma Link. The Wichita and the Oklahoma City sit-ins came in close proximity, Wichita in July and August of 1958 and Oklahoma City two weeks after. Although we cannot conclude that one was the cause of the other or that the adaptive response was direct, the Oklahoma NAACP officials, presumably including Clara Luper, and even white store managers, knew of the Wichita sit-in that had recently taken place only two hundred miles away.

The Oklahoma-Greensboro Link. The Oklahoma sit-ins achieved national prominence and lasted for nearly five years. By 1959 the NAACP national office claimed the sit-ins as part of their legacy. The December 1958 issue of The Crisis carried a picture of Oklahoma youths demonstrating at Brown's lunch counter with a story by Barbara Posey and Gwendolyn Fuller, leaders of the movement. ${ }^{41}$

The NAACP Annual Report for 1959 carried stories of actions taken by other youth 
chapters against eating facilities. The Washington University chapter of the NAACP started a protest against discrimination by the off-campus Santora restaurant, later taken up by the St. Louis adult branch. After campuswide protests and a court decision, the Santora restaurant changed its policy. The University of Chicago chapter picketed the Tropical Hut Restaurant near its campus for advertising for a "white waitress" and forced the restaurant to change its employment policy. The University of Indiana chapter at Bloomington was successful in its campus-wide protest against barber shops that refused black customers, and the Ohio State University chapter successfully challenged the administration to prohibit discrimination in off-campus housing. ${ }^{42}$

Indeed, at the 1959 NAACP Convention, Dr. Martin Luther King, Jr., himself presented citations to the NAACP youth councils of Oklahoma City and St. Louis that had initiated sit-ins. ${ }^{43}$ So important had the youth protest movement become within the NAACP that the national organization devoted its fiftyfirst annual conference in 1960, to an "Accent on Youth," hosting 349 youths from 49 states. The conferees held a special "Youth Freedom Fund Dinner" to raise money for their activities. In his keynote address to the convention, Robert C. Weaver stated that: "NAACP youth units in Wichita, Kansas [sic] and Oklahoma City started these demonstrations in 1958 and succeeded in desegregating scores of lunch counters in Kansas and Oklahoma. The 'sit-in' is not a new tactic for the NAACP." John Morsell restated the same fact at the conference workshops. ${ }^{44}$

In his foreword to the 1960 NAACP Annual Report, Executive Director Roy Wilkins, made the direct linkage between the Great Plains sit-ins and the Greensboro event:

The student uprising was spontaneous. No organization, whether new or old, or yet unformed, can claim to have planned and initiated the start of the wave on February 1,1960 . But of the four original lunch counter sit-in students, two were members of a student chapter of the NAACP. Two years before, youth chapters of the NAACP in Wichita, Kansas, and in Oklahoma City, Okla.[sic] had staged successful pilot sit-in campaigns in those cities [sic] winning lunch counter desegregation in sixty or more stores. ${ }^{45}$

At least in the mind of the NAACP executive director there was a direct link between the "pilot" Wichita and Oklahoma sit-ins and the Greensboro sit-in, in the form of Greensboro participants who were members of the NAACP youth network and presumably had knowledge of the earlier sit-ins. In fact, Joseph McNiel and Ezell Blair, the two students mentioned by Wilkins, had both attended the 1960 Accent on Youth conference and reported on the Greensboro sit-ins. ${ }^{46}$

Nevertheless, by the time the 1960 Annual Report of the NAACP was being written, the Greensboro tide had swept the South and the Student Non-violent Coordinating Committee-rather than the NAACP-was receiving the lion's share of the credit. Wilkins's remarks seemed to strike a defensive tone, since the NAACP had been late in throwing its full support behind the activities of its own youth.

This defensiveness suggests the tensions that had begun to unfold among the "Big Five" civil rights organizations and FOR, which had earlier pioneered non-violent methods, including the sit-ins. According to August Meier and Elliot Rudwick, for example:

CORE's advocacy of direct action was by no means a denigration of the NAACP's valuable contribution to the civil rights movement. Privately, however, they recognized that after the southern student movement began in February, "Everywhere under the surface there were conflicts between the NAACP and other race relations organizations. CORE leaders were especially annoyed at the NAACP's claim-based upon [a] variety [of] store demonstrations sponsored by the Oklahoma City NAACP Youth Council in 1958 - to have started the southern student sit-ins." ${ }^{47}$ 
Rudwick and Meier suggest that the NAACP, the oldest and most venerated civil rights organization, was forced to defend its turf by new organizations that emerged in the 1960s.

It may be that rivalry among the civil rights organizations is one reason the Great Plains sit-ins have received so little notice. Other groups focusing on their own accomplishments have downplayed the linkage between the Great Plains sit-ins and those in the South. This perspective may have been adopted and perpetuated by scholars of the southern movement as well.

In any case, the actions of northern NAACP youth chapters in 1958 and 1959 were not "isolated" from the southern chapters of the NAACP-nor other organizations-and the campaigns of the northern chapters against segregated eating establishments constituted a national model and network for change by the time the Greensboro sit-in began. The direct participation of NAACP youth chapter members in the Greensboro sit-in further strengthens the ties between the northern and southern sit-ins.

Thus, it is not only important that the Wichita and Oklahoma sit-ins are linked to each other, and to Greensboro, but as Morris says, to thirteen other cities where sit-ins occurred before Greensboro. Are these actions, which occurred in Great Plains, border, and southern states an unimportant part of the expansion of civil rights activity, or is Morris correct in concluding that "there were important similarities in the entire chain" of sit-ins from 1958 through the mid-1960s? $?^{48}$ The Great Plains sit-ins and the southern sit-ins occurred within the same environmental conditions and time frame and used the same organizational networks to confront racial exclusion. The northern sit-ins constitute the beginnings of the continuum of action that resulted in the southern movement.

\section{CONCLUSION}

Among the environmental factors leading to the sit-ins, the most significant in the emer- gence and sustenance of the movement were racism and the race organizations that developed to oppose it.

Racism, of course, was encountered by blacks in the urban environment as the effects of the slavocracy of the rural South extended to the northern cities, resulting in patterns of exclusion of blacks from both public accommodations and private social functions. In both rural and urban environments, the freedom movement has confronted racism's iniquities.

Second, racism provoked various specific responses. The primary cause of sit-ins was the particular discrimination found in a specific restaurant. In the planning stages of both the Wichita and the Oklahoma City movements, however, plans were not directed at only one establishment; instead, protests against one or a series of establishments became a strategy to break down segregation in a variety of eating facilities. More important than the practices of any particular restaurant is the category of racism that expressed itself in discrimination in eating establishments.

Third, there are many ways to interpret the connections among events. Different actors may logically develop the same responses to similar problems. If, however, the actors know how someone else has resolved a similar problem in the past, they may adopt the same style to deal with their own problem. ${ }^{49}$ Thus young people in Greensboro may have reacted to lunch counter discrimination with a sit-in not because of the Wichita and Oklahoma City sit-ins but because of their own unwillingness to tolerate discrimination. At the same time the style and rhythm of the Greensboro protest seem to have been colored by the earlier sit-ins.

Finally, in order to determine in what ways sit-ins stimulated other tactics in opposition to racism, it is important to discover precisely what precipitating factor was responsible. The two sit-ins examined in this study responded to cues in the northern urban environment and became matches that helped to light the modern phase of the southern civil rights movement. The Great Plains sit-ins were not 
isolated phenomena. Each was linked to the vital process of the entire movement for social justice.

\section{NOTES}

1. David Levering Lewis, "The Origins and Causes of the Civil Rights Movement," in The Civil Rights Movement in America, ed. Charles Eagles (Jackson: University Press of Mississippi, 1986), p. 7, emphasis added; Doug McAdam, Political Process and the Development of Black Insurgency (Chicago: University of Chicago Press, 1982), p. 134.

2. See, for example, Warren St. James, NAACP: Triumphs of a Pressure Group, 1909-1980 (Smithtown, New York: Exposition Press, 1980).

3. "Editor Says Press Plays Down Northern Discord," U.S. News Eु World Report 40 (23 March 1956): 48,49; "Southerner Says Race Trouble in North Not 'Page One,"' Ibid., p. 50.

4. "The Negro in the North," Time 67 (4 June 1956): 81-82.

5. Howard Zinn, SNCC: The New Abolitionists (Boston: Beacon Press, 1964) p. 26.

6. Aldon Morris, "Black Southern Student SitIn Movement: An Analysis of Internal Organization," American Sociological Review 46 (December 1981): 744-67. See also his comprehensive study of this subject, The Origins of the Civil Rights Movement: Black Communities Organizing for Change (New York: The Free Press/Macmillan, 1984), pp. 188-94.

7. McAdams, Political Process (note 1 above), p. 134.

8. Morris, "Black Southern Student Sit-In" (note 6 above), p. 750 .

9. Ibid.

10. Morris, Origins of the Civil Rights Movement (note 6 above), p. 193.

11. See Ronald Walters, "The 'First' Civil Rights Sit-In," American Visions 8 (No. 1, February/March 1993): 20-23

12. Bureau of the Census, U.S. Census of Population, Vol. 1, 1970, Parts A and B.

13. "Boom and a City," Newsweek 46 (12 December 1955): 60 .

14. E.C. Ford, "A Horrible Blot on the Fair Name of Kansas," Negro History Bulletin 19 (No. 2, November 1955).

15. Matthew Schofield, "The Forgotten Sit-In," Kansas City Star, 21 January 1991, p. D8.

16. Memorandum, Carol Parks-Hahn to Ronald Walters, December 1990. Carol Park's mother, the then Mrs. Vivian Parks, served as secretary-treasurer of the local NAACP and was in frequent contact with the national officers.
17. Chester Bowles, "What Negroes Can Learn From Ghandi," Saturday Evening Post 230 (1 March 1958): 19-21.

18. "Negroes 'sit down' in Wichita Restaurants," Facts on File, Five-Year Index, 1956-60, 18-21August 1958; "Oklahoma 'Sit-Down." Facts on File, Vol. 18, No. 931, 28 August-3 September, p. 285. This article erroneously says that the Wichita Sitin took place over the period 17-21 August. See also, a local black newspaper that carried the story of the NAACP Thalheimer Award, Class I, being presented to the Wichita NAACP chapter, in part for the following: "One of the major achievements was the orderly protest made by the NAACP Youth Council last July [my emphasis] against discrimination in eating facilities at Dockum Drug Store." "Wichita NAACP Cite for Award," Enlightener 2 (9 July 1959): 1.

19. "Drug Store Picketed by NAACP," Wichita Eagle, 3 August 1958, p. C1.

20. Matthew Schofield, "The Forgotten Sit-In," Kansas City Star, 21 January 1991, p. 3.

21. "Dockum Fountain Service Now Open to All Wichita Citizens," Enlightener, no. 9, $14 \mathrm{Au}$ gust 1958, p. 1.

22. Parks-Hahn to Walters (note 16 above).

23. Schofield, "Forgotten Sit-In" (note 20 above).

24. "Dockum Fountain Service Now Open," (note 21 above).

25. U.S. Bureau of the Census, Census of Population, 1970, Vol. 1, Parts A and B.

26. For a comprehensive account of the Oklahoma sit-ins and NAACP politics, see, Clara Luper, Behold The Walls (Oklahoma City: Jim Wire, 1979).

27. "Negro Drive Spreads to Enid," Daily Oklahoman, 27 August 1958, unpaginated photocopy, Newspaper Archives, Oklahoma Historical Society.

28. "Negro Group Sitting at City Drug Store," Daily Oklahoman, 20 August 1958, p. 1.

29. "Katz Fountain Gives Negro Group Service," Daily Oklahoman, 22 August 1958, p. 1.

30. "Negro Youths Store Sitting in Fourth Day," Daily Oklahoman, 23 August 1958, p. 1.

31. "Oklahoma City NAACP Youth Council Speaks," Black Dispatch, 26 September 1958, p. 2.

32. "104 Negroes Mill In Cravens Lobby," Daily Oklahoman, 11 August 1960, p. 1.

33. Kyle Ragland, "Minister Teaches Art of NonViolent Protest," untitled photocopy, 10 October 1960, Newspaper Archives, Oklahoma Historical Society.

34. "Today Is For Youth," Black Dispatch, 20 February 1959 , p. 5 .

35. "NAACP Leaders Back 'Sitdowns," Daily Oklahoman, 1 September 1958. 
36. "No Sitdown For Adults," untitled photocopy, 1 September 1958, Newspaper Archives (note 33 above).

37. "Ban Sought On Sitdowns," United Press International, 27 August 1958.

38. Allen Cromley, "U.S. Turns Deaf Ear To City Race Crusade," Oklahoma City Times, 11 September 1958.

39. "Enid Restaurants Advised on 'Strike,"' untitled photocopy, 29 August 1958, Newspaper Archives (note 33 above).

40. Morris and Carson quoted in Schofield, "Forgotten Sit-In" (note 20 above).

41. "Protest Drug Counter Discrimination,"Crisis 65 (No. 10, December 1958): 612.

42. "The Year of Jubilee," NAACP Annual Report for 1959, 1960, pp. 36-37.

43. Ibid., p. 86 .
44. Gloster B. Current, "Fifty-first Annual NAACP Convention-Accent on Youth," Crisis 67 (No. 7, August-September 1960): 407, 418.

45. NAACP Annual Report for 1960, 1961, p. 5, emphasis added.

46. Current, "Accent on Youth" (note 44 above), p. 414.

47. Meier and Rudwick quote in this statement sentiment from CORE documents from the period in question. August Meier and Elliot Rudwick, CORE: A Study in the Civil Rights Movement, 19421968, New York: Oxford University Press, 1973, p. 105.

48. Morris, Origins of the Civil Rights Movement (note 6 above), p. 189.

49. Robert C. Carson, Interaction Concepts of Personality (Chicago: Aldine Publishing, 1969), p. 5 . 